\title{
COMPETITIVE PROTEIN-BINDING ASSAY OF PROGESTERONE IN BOVINE JUGULAR VENOUS PLASMA DURING THE OESTROUS CYCLE
}

\author{
M. SHEMESH, H. R. LINDNER* AND N. AYALON \\ Department of Reproduction, The Veterinary Research Institute, Beth-Degan, and \\ *Department of Biodynamics, Weizmann Institute of Science, Rehovot, Israel
}

\section{(Received 2nd September 1970, revised 18th Fanuary 1971)}

\begin{abstract}
Summary. A rapid radiometric assay based on thin-layer-chromatography and the competition by progesterone for binding sites on the corticosterone-binding globulin of human plasma was used to determine changes in the level of progesterone in peripheral bovine plasma during the oestrous cycle. The blood level (ng/ml, mean \pm S.E.) of the hormone was minimal $(0 \cdot 6 \pm 0 \cdot 15$ to $0 \cdot 8 \pm 0 \cdot 20)$ from Day -2 to +2 of the cycle (Day $0=$ day of oestrus), rose steeply between Day 3 and Day 7 , and either continued to rise very slowly or maintained a plateau fluctuating about a mean of $5 \cdot 4 \pm 0 \cdot 16$ for 8 to 10 days, before declining; the most abrupt fall in plasma progesterone concentration occurred on Day -4 or -3 . The results agreed well with control data obtained by sequential paper- and gas-chromatography $(r=0.93)$.
\end{abstract}

\section{INTRODUCTION}

The peripheral plasma level of progesterone furnishes a valuable indication of the concentration of the hormone reaching the target organs and the control centres governing the secretion of gonadotrophins, at various phases of the reproductive cycle. Alterations in circulating progesterone level, unless determined by changes in peripheral metabolism, also supply information on the functional state of the corpus luteum, or of alternative sources of the hormone such as the adrenal or placenta. Detailed information concerning this parameter is thus essential for a meaningful application of the concepts of systems analysis and control engineering to the study of the oestrous cycle (see Schwartz, 1969).

A barrier to the collection of such data has been the large plasma volume required for a single analysis, in view of the low progesterone levels in the nonpregnant animal: 300 to $500 \mathrm{ml}$ are needed for assays based on u.v. spectrophotometry, about 50 to $80 \mathrm{ml}$ for gas-liquid-chromatography (GLG) with hydrogen-flame-ionization detection, or $20 \mathrm{ml}$ when an electron-capture detecting device was used (Stabenfeldt, Ewing \& McDonald, 1969). A further barrier was the amount of skilled labour required for assays based on either double isotope derivative of GLC methods. 
In the present study, the principle of ligand displacement or 'competitive protein binding' (GPB), as outlined by Murphy (1969), was utilized to determine progesterone rapidly in samples of 0.5 to $1 \mathrm{ml}$ bovine plasma collected at known stages of the oestrous cycle, and the results so obtained were compared with data obtained by a GLC method of established specificity, accuracy and precision.

\section{MATERIALS AND METHODS}

Samples of blood were collected between 07.30 and 08.00 hours from the jugular veins of cows of Friesian type with normal cycle length (20 to 23 days), free from venereal infection or demonstrable lesions of the reproductive tract, at known stages of the oestrous cycle. Oestrous behaviour was detected by use of a bull with a surgically deflected penis. The time of ovulation was determined by twice-daily rectal palpation during oestrus and on the day following it. Only cows exhibiting both ovulatory and behavioural oestrus were included in this study. Blood samples were also obtained from a cow 26 days after bilateral ovariectomy. The blood was drawn into vessels containing sodium citrate or heparin and cooled rapidly to $4^{\circ} \mathrm{C}$ and stored at $-18^{\circ} \mathrm{C}$ until required for analysis.

Progesterone was determined in the plasma by one or two of the following methods.

\section{Method 1 (paper- and gas-liquid-chromatography)}

This method consisted of extraction of the plasma sample $(80 \mathrm{ml})$ as described by Lindner, Lunenfeld \& Shelesnyak (1967) and determination of progesterone in these extracts by sequential paper- and gas-liquid-chromatography (PC/ GLC), using a hydrogen-flame detector (Lindner \& Zmigrod, 1967). A radioactive internal recovery standard was used to compensate for losses incurred during analysis.

The limit of sensitivity of this method was 1.2 to $1.5 \mathrm{ng} / \mathrm{ml}$ progesterone. No progesterone $(<1.5 \mathrm{ng} / \mathrm{ml})$ was detected in the blood of the ovariectomized cow. When progesterone $(5 \mathrm{ng} / \mathrm{ml})$ was added to this plasma, the mean progesterone concentration found in twelve replicate determinations was 5.4 $\mathrm{ng} / \mathrm{ml} \pm 0.024$ S.E. The standard deviation of a single determination of progesterone at plasma levels of 4 to $7 \mathrm{ng} / \mathrm{ml}$ was 8 to $13 \%$ in different trial series.

\section{Method 2 (thin-layer-chromatography and competitive protein binding)}

This method was based on the competition between progesterone and tritiumlabelled corticosterone for binding sites on the corticosteroid-binding globulin (CBG; Johansson, 1969). Before application of this technique, progesterone was separated from the plasma extracts by thin-layer-chromatography (TLC; Neill, Johansson, Datta \& Knobil, 1967). Generally, $0.5 \mathrm{ml}$ of plasma was extracted with 10 vol petroleum ether (b.p. 30 to $60^{\circ} \mathrm{C}$; Mallinckrodt Lot PTEX No. 4980). When low progesterone levels were expected (e.g. during the 3 days before, and 4 days after, ovulation), $1.0 \mathrm{ml}$ plasma was used for the 
assay. All assays were carried out in duplicate, and a petroleum ether extract of $1 \mathrm{ml}$ water, serving as a blank, was included in each run. The extracts, dried under a stream of nitrogen at $50^{\circ} \mathrm{C}$, were transferred in methanol $(3 \times 50 \mu \mathrm{l})$ to factory-coated TLC sheets (Eastman Chromatogram Sheet 6060, silica gel with fluorescent indicator), alongside a progesterone reference sample. Before use, the sheets were washed by overrunning with four solvents as recommended by Rosenfield, Eberlein \& Bongiovanni (1969), followed by a further wash with the solvent system (diethyl ether/benzene $2: 1$ ) to be used for development of the chromatograms. The sheets were then dried at $80^{\circ} \mathrm{C}$ for $30 \mathrm{~min}$ and stored in the desiccator until required.

The progesterone standard was detected on the developed chromatograms by examination under ultraviolet light. The corresponding areas $(2.5 \times 3.5 \mathrm{~cm})$ on the lanes carrying the extracts were cut out and eluted by overrunning the segments chromatographically with $4 \mathrm{ml}$ methanol. The eluate was dried under a stream of nitrogen at $45^{\circ} \mathrm{C}$.

The source of CBG was pooled blood plasma from women receiving either combined oral contraceptive pills (Metrulen-M, G. D. Searle and Co. brand of ethynodiol diacetate $1.0 \mathrm{mg}$, plus mestranol $0.1 \mathrm{mg}$, one pill daily) for 15 to 19 days before sampling, or $100 \mu \mathrm{g}$ ethinyloestradiol daily for at least 2 weeks. The plasma was stored at $-20^{\circ} \mathrm{C}$. The optimal dilution of the CBG (usually $1000-$ to 2000-fold) was determined for each batch of plasma and the diluted solutions were used within $24 \mathrm{hr}$. Other details of the protein-binding assay were as described by Johansson (1969). A calibration curve, based on tubes containing known amounts $(0.2$ to $5 \mathrm{ng})$ of pure progesterone, was prepared for each assay.

Using this method, the progesterone concentration in the plasma of the ovariectomized cow was found to be $0.6 \mathrm{ng} / \mathrm{ml}$. The reagent blank (water extract) was $<0.1 \mathrm{ng} / \mathrm{ml}$. Varying amounts of progesterone $(0.5$ to $4.4 \mathrm{ng} / \mathrm{ml})$, within the range commonly found in the peripheral blood of cows during the oestrous cycle, were added to plasma from the ovariectomized cow. The mean recovery of the added steroid as estimated by the TLC/CPB assay was $84 \cdot 1 \% \pm$ S.E. 3.26. In routine assays, the procedure was rigidly standardized and the results reported have been corrected for losses during analysis, assuming a uniform recovery rate of $80 \%$.

\section{Method 3 (competitive protein binding)}

This method was similar to Method 2 in all respects, except that the TLC step was eliminated. The rapid method is based on the observation that certain batches of petroleum ether will selectively extract progesterone from plasma, while extracting only minimal amounts of other steroids (such as $17 \alpha$-hydroxyprogesterone and 20-dihydroprogesterone) able to interfere with the CPB assay (Murphy, 1967; Johansson, 1969).

\section{RESULTS}

Direct comparison of competitive protein-binding and gas-chromatographic assay methods Twenty-seven plasma samples were analysed both by Method 1 (PC/GLG) 
and Method 2 (TLC/GPB). Text-figure 1 shows the regression of the progesterone level obtained by TLC/CPB on that obtained by PC/GLG. There was fairly close correspondence between the two sets of data $(r=0.93 ; P<0.001)$.

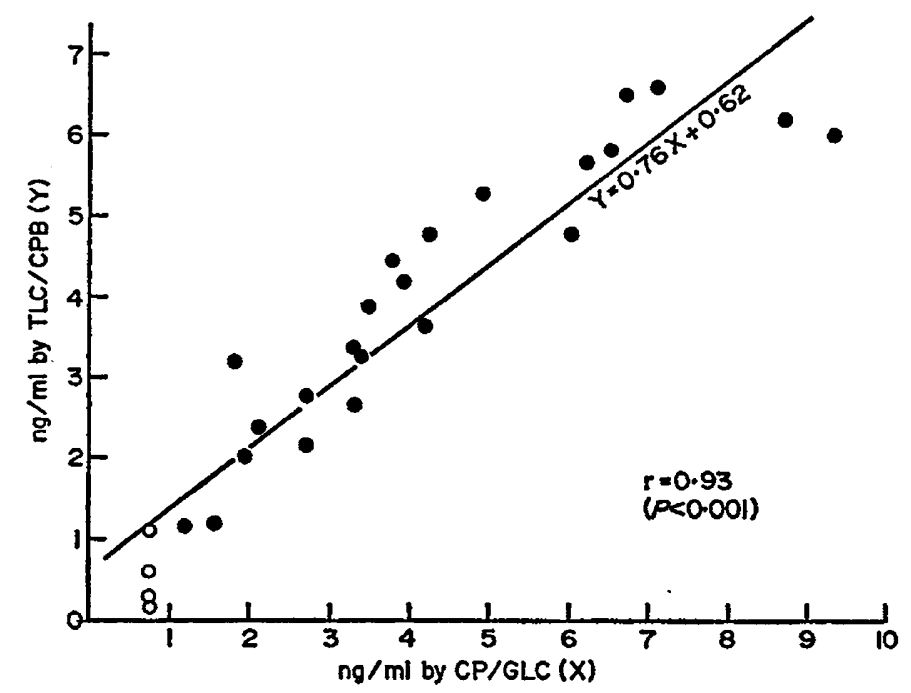

TEXT-FIo. 1. Comparison between plasma progesterone values obtained by TLC competitive protein-binding assay $(Y)$ and by sequential paper- and gas-chromatography (X).

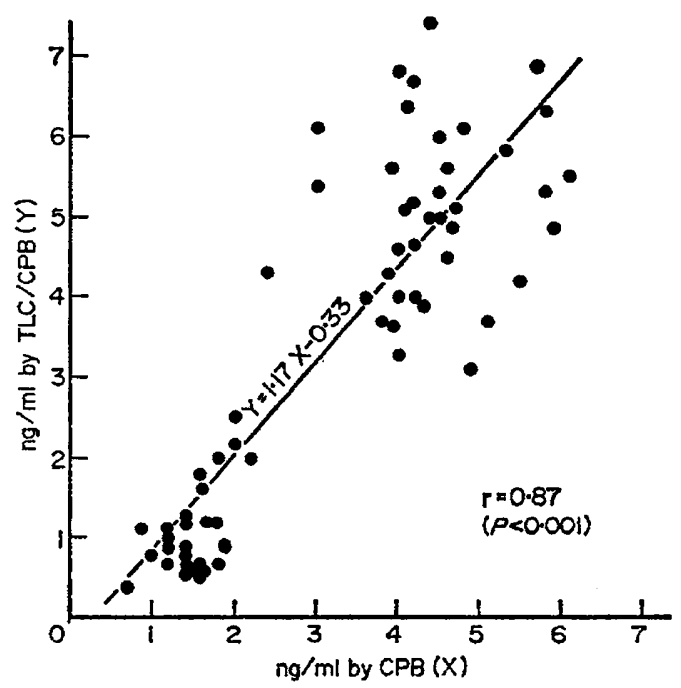

TEXT-Fro. 2. Comparison between plasma progesterone values obtained by competitive protein-binding assay with or without prior purification by TLG.

The standard deviation of the difference (d) between pairs of values obtained for the same plasma sample by the two methods (estimated as $s=\sqrt{ }\left(\Sigma d^{2} / 2 N\right)$, where $\mathrm{N}$ is the number of pairs) was $0.68 \mathrm{ng} / \mathrm{ml}$. 
Sixty-five plasma samples were examined both by Method 2 and the abbreviated Method 3. The corresponding regression is shown in Text-fig. 2. High level (luteal phase) and low level (periovular phase) samples are well separated by either method, but there is considerable scatter about the regression line. The slope of this line $(1 \cdot 17)$ may have been affected by residual impurities derived from the TLC plates that occasionally give higher readings by Method 2; on the other hand, during the follicular phase somewhat higher and possibly erroneous values were obtained when the TLC step was omitted (Method 3). These may have been due to competition by steroids other than progesterone extracted from plasma. The standard deviation of the difference between values obtained for the same sample by the two methods was estimated (see above) as 0.80 $\mathrm{ng} / \mathrm{ml}$.

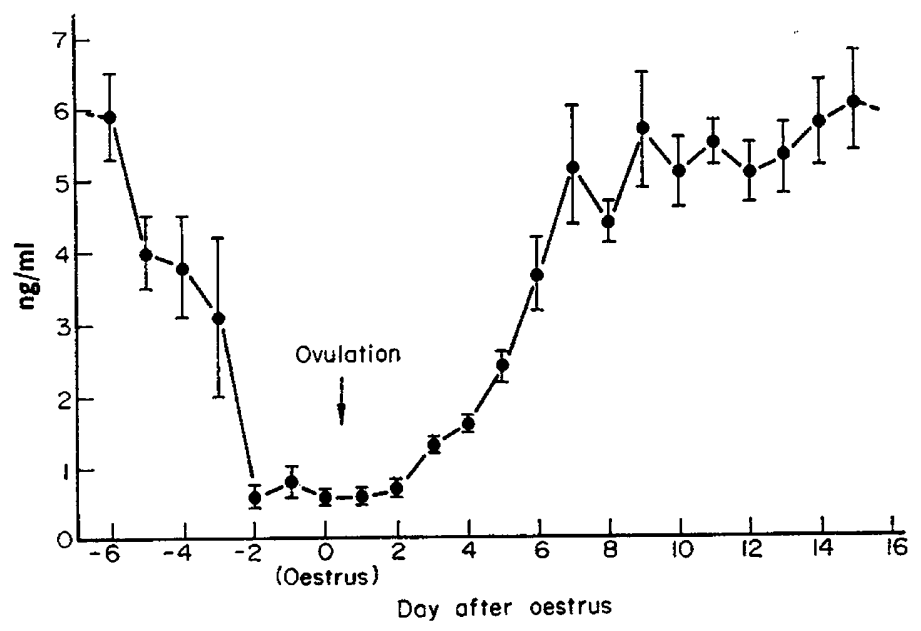

Text-Fig. 3. Peripheral plasma progesterone levels in cows during the oestrous cycle (TLC/CPB method). Cycle length 20 to 22 days; vertical bars indicate \pm S.E.

\section{Cyclic changes in peripheral plasma progesterone level in non-pregnant cows}

The data obtained by three methods relating the plasma progesterone level to the stage of the oestrous cycle are summarized in Table 1. In order to combine data obtained from cows with different cycle length, the day of oestrus was taken as Day 0 of the cycle; thereafter, the days were numbered 1 to 13-15 (for 20- to 23-day cycles, respectively); the 6 days preceding oestrus were designated, retrospectively, Days -6 to -1 , since the striking preovulatory fall in progesterone level (see below) seemed more consistently related in time to the succeeding than the preceding oestrous period.

Text-figure 3 represents the data for the most extensive series, that determined by the combined TLC/CPB method (187 samples). The progesterone level showed a nadir (mean values 0.6 to $0.8 \mathrm{ng} / \mathrm{ml}$ ) from Day -2 to Day +2 , rose steeply between the 3rd and 7th day of the cycle, and then tended to rise very slowly or maintained a plateau, fluctuating about a mean of $5.4 \mathrm{ng} / \mathrm{ml} \pm$ S.E. $0 \cdot 16$, until the 6 th day before the succeeding oestrus. The progesterone level then 
declined, most steeply in this series between the 3rd and 2nd day before oestrus though, in some of the cows, the most abrupt fall occurred between Days -4 and -3 . Hence, the progesterone level on Day -3 was the most variable of the cycle (coefficient of variation, $35 \%$ ).

In the series of cows examined by the rapid protein binding method (without TLC), the steepest fall in progesterone level occurred between the 4th and 3rd days before oestrus (Table 1 ). The values obtained for the periovular period (Days -2 to +3 ) were somewhat higher than in the TLC/CPB series (mean 0.8 to $1 \cdot 6$ ), but were still the lowest of the cycle. From Day 6 to Day -5 , the level fluctuated about a mean of $4 \cdot 4 \mathrm{ng} \pm 0 \cdot 15$ S.E.

TABLE 1

PROGESTERONE IN SYSTEMIC PLASMA OF COWS DURING THE OESTROUS GYCLE

\begin{tabular}{|c|c|c|c|}
\hline \multirow[b]{2}{*}{$\begin{array}{l}\text { Day before }(-) \\
\text { or afier oestrus }\end{array}$} & \multicolumn{3}{|c|}{ Plasma progesterone $(\mathrm{ng} / \mathrm{ml} ;$ mean \pm S.E. $)$} \\
\hline & $\begin{array}{c}C P B \\
\text { (Rapid method) }\end{array}$ & $T L C / C P B$ & $\begin{array}{c}P C / G L C \\
\text { (Flame ionization) }\end{array}$ \\
\hline $\begin{array}{c}-6 \\
-5 \\
-4 \\
-3 \\
-2 \\
-1 \\
\text { Oestrus } \\
1 \\
2 \\
3 \\
4 \\
5 \\
6 \\
7 \\
8 \\
9 \\
10 \\
11 \\
12 \\
13 \\
14 \\
15 \text { to } 16\end{array}$ & $\begin{array}{l}5 \cdot 1 \pm 0.46 \\
4 \cdot 2 \pm 0.27 \\
3.7 \pm 0.36 \\
1.6 \pm 0.29 \\
1.3 \pm 0.08 \\
0.8 \pm 0.07 \\
1 \cdot 6 \pm 0.15 \\
1 \cdot 6 \pm 0.24 \\
1.5 \pm 0.17 \\
1 \cdot 6 \pm 0.22 \\
2.0 \pm 0.20 \\
2 \cdot 6 \pm 0.35 \\
4 \cdot 2 \pm 0.34 \\
3 \cdot 6 \pm 0.53 \\
4.8 \pm 0.36 \\
3.9 \pm 0.25 \\
4 \cdot 1 \pm 0.20 \\
4.5 \pm 0.63 \\
3.8 \pm 0.44 \\
4.7 \pm 0.38 \\
4.9 \pm 0.29 \\
5.2 \pm 0.55\end{array}$ & $\begin{array}{l}5.9 \pm 0.59 \\
4 \cdot 0 \pm 0.49 \\
3.8 \pm 0.71 \\
3.1 \pm 1.09 \\
0.6 \pm 0.15 \\
0.8 \pm 0.20 \\
0.6 \pm 0.08 \\
0.6 \pm 0.09 \\
0.7 \pm 0.12 \\
1 \cdot 3 \pm 0.08 \\
1 \cdot 6 \pm 0.14 \\
2.4 \pm 0.23 \\
3.7 \pm 0.47 \\
5.2 \pm 0.79 \\
4.4 \pm 0.31 \\
5.7 \pm 0.82 \\
5.1 \pm 0.50 \\
5.5 \pm 0.28 \\
5.1 \pm 0.40 \\
5.3 \pm 0.54 \\
5.8 \pm 0.59 \\
6.1 \pm 0.72\end{array}$ & $\begin{aligned} & 4 \cdot 1 \pm 0.36 \\
& 4 \cdot 1 \pm 0.46 \\
& 5.2 \pm 0.97 \\
& 5.6 \pm 0.50 \\
&<1.2 \\
&<1.2 \\
&<1.2 \\
&<1.2 \\
&<1.2 \\
&<1.2(<1.2 \text { to } 1.7) \\
&<1.2(<1.2 \text { to } 1.7) \\
&<1.2(<1.2 \text { to } 1.5) \\
& 1.8(<1.2 \text { to } 2.2) \\
& 2.7 \pm 0.28 \\
& 2.9 \pm 0.29 \\
& 3.8 \pm 0.58 \\
& 3.8 \pm 0.42 \\
& 4.7 \pm 0.85 \\
& 3.5 \pm 0.39 \\
& 4.5 \pm 0.97 \\
& 4.5 \pm 0.58 \\
& 3.7\end{aligned}$ \\
\hline
\end{tabular}

CPB (total 160 samples); TLC/CPB (187 samples); PG/GLG (104 samples; data condensed from Shemesh et al., 1968a). For details see Methods section.

Gas chromatographic data, previously published (Shemesh, Ayalon \& Lindner, 1968a), are shown for comparison (Table 1). Flame-ionization detection permitted only the definition of an upper limit $(1.2 \mathrm{ng} / \mathrm{ml})$ for the nadir of the cycle (Days -2 to +2 ). Few cows had measurable progesterone levels $(1.5$ to $1.7 \mathrm{ng} / \mathrm{ml}$ ) on Days 3 to 5 . The luteal plateau extended to Day -3 (mean $4.3 \mathrm{ng} / \mathrm{ml} \pm 0 \cdot 20$ S.E., Days 9 to -3 ), so that the fall between the 3rd and 2nd days before oestrus was even more abrupt.

\section{DISCUSSION}

The results presented indicate that a rapid method for determining plasma 
progesterone, based on the competition of progesterone for binding sites on the corticosterone-binding globulin of human plasma (see Murphy, 1969), can be applied to bovine peripheral plasma and yields results that are compatible with those obtained by much more exacting gas-liquid-chromatographic procedures (Shemesh, Ayalon \& Lindner, 1968a, b; Pope, Gupta \& Munro, 1969; Stabenfeldt $e t$ al., 1969). The method requires only small plasma samples $(0.5$ to $1.0 \mathrm{ml})$ and permits the performance of twenty to thirty analyses per day by a single operator. The closest correspondence of the analytical results with PC/GLC data was obtained when progesterone was separated from the plasma extracts by TLC before application of the CPB assay, a method preferred in this laboratory. However, even without the TLC step, the CPB method clearly distinguished between samples collected during the periovular and luteal phase, though the former appeared to be somewhat overestimated.

A study by Henricks, Roland \& Hill (1969), published in abstract form, also indicated that a CPB method can be used to determine plasma progesterone in the bovine; but Rao \& Estergreen (1969) found that only the lowest (Day 2) and highest (Day 18) plasma progesterone values of the cycle could be distinguished by use of CPB. Moreover, the values for the periovular phase of the cycle obtained by the latter authors $(2.85$ and $2.69 \mathrm{ng} / \mathrm{ml}$ on Days 0 and 2, respectively) appear unduly high.

The day-to-day changes observed in the plasma progesterone concentration of non-pregnant cows by means of the TLC/CPB assay present a cyclic pattern, characterized by minimal plasma progesterone levels $(0.6$ to $0.8 \mathrm{ng} / \mathrm{ml})$ on the 2 days preceding and the 2 days following ovulation, a sharp rise from the 3rd to 7 th day of the cycle, followed by a very slow rise or a plateau lasting for 8 to 10 days, with fluctuations about a mean of $5.4 \mathrm{ng} / \mathrm{ml}$. Plotka, Erb, Callahan \& Gomes (1967), who used a double isotope derivative assay, reported four to twenty times higher values, but the specificity of the method used by these authors has since been questioned (Stabenfeldt et al., 1969).

A striking feature of the bovine cycle is the abrupt fall in the peripheral progesterone level, observed in our series usually between the 4th and 3rd, or the 3rd and 2nd days before oestrus. Since this fall is not seen in pregnant animals, an early pregnancy diagnosis can be made at this time by plasma progesterone determinations (Shemesh et al., 1968b; Pope et al., 1969). Stabenfeldt et al. (1969) found that the time interval between the decline of progesterone and the occurrence of oestrus ranged from 1 to 5 days and attributed this to variation in the time required for follicle development and maturation. Our impression is that cycle length is determined chiefly by variation in the duration of luteal function rather than of follicle development.

A preovulatory rise in ovarian progesterone secretion, analogous to that observed in rodents, could not be demonstrated in the cow.

Since the cyclic changes observed in peripheral plasma progesterone levels roughly parallel those of luteal progesterone synthesis in vitro (Armstrong \& Black, 1966), luteal progesterone content (Erb \& Stormshak, 1961) and progesterone secretion into the ovarian venous blood (Dobrowolski, Stupnicka \& Domanski, 1968), one may assume that the metabolic clearance rate of progesterone remains more or less steady throughout the oestrous cycle. The 
view that peripheral plasma progesterone levels in the cow bear no consistent relationship to the oestrous cycle (Gomes, Estergreen, Frost \& Erb, 1963) can certainly no longer be maintained.

\section{ACKNOWLEDGMENTS}

We are grateful to Dr E. D. B. Johansson for helpful advice, to Mr I. Baram and Mr I. Lewis for skilful technical assistance, and to the Ford Foundation and Population Council (Grant M65-143 to H. R. L.) and the U.S. Department of Agriculture (Grant FG-IS-159, PL 480, to N.A.) for financial support.

This work was carried out in partial fulfilment of the requirements for the Ph.D. degree (M. Shemesh) at the Graduate School of the Weizmann Institute of Science.

\section{REFERENGES}

ARmstrong, D. T. \& BLACK, D. L. (1966) Influence of LH hormone on corpus luteum metabolism and progesterone biosynthesis throughout the bovine oestrous cycle. Endocrinology, 78, 937.

Dobrowolski, W., Stupnicka, E. \& Domanski, E. (1968) Progesterone levels in ovarian venous blood during the oestrous cycle of the cow. F. Reprod. Fert. 15, 409.

ERB, R. E. \& StoRmshak, F. (1961) Progestins in corpora lutea, ovaries, and adrenals after estrus and breeding of normal and abnormal cows. 7. Dairy Sci. 44, 888.

Gomes, W. R., Estergreen, V. L., JR, Frost, O. L. \& ERB, R. E. (1963) Progestin levels in jugular and ovarian venous blood, corpora lutea and ovaries of the non-pregnant bovine. F. Dairy Sci. 46, 553.

Henricks, D. M., Roland, R. D. \& Hils, J. R. (1969) Progesterone secretion in the cycling and pregnant cow. Fedn Proc. Fedn Am. Socs exp. Biol. 28, Abstr. 2870.

Johansson, E. D. B. (1969) Progesterone levels in peripheral plasma during the luteal phase of the normal human menstrual cycle measured by a rapid competitive protein binding technique. Acta endocr., Copenh. 61, 592.

LindNer, H. R., Lunenfeld, B. \& ShelesNyak, M. G. (1967) Plasma levels of progesterone and cortisol, and urinary pregnanediol excretion, during the post-ovulatory phase of the cycle in normal and ergocornine-treated women. Acta endocr., Copenh. 56, 35.

LiNDNER, H. R. \& ZMigrod, A. (1967) Microdetermination of progestins in rat ovaries. Acta endocr., Copenh. 56, 16.

Murphy, B. E. P. (1967) Some studies of the protein-binding of steroids and their application to the routine micro and ultramicro measurement of various steroids in body fluids by competitive protein-binding radioassay. 7. clin. Endocr. Metab. 27, 973.

Murphy, B. E. P. (1969) Protein binding and the assay of nonantigenic hormones. Recent Prog. Horm. Res. 25, 563.

Neill, J. D., Johansson, E. D. B., DAtTA, J. K. \& Knobir, E. (1967) Relationship between the plasma levels of luteinizing hormone and progesterone during the normal menstrual cycle. 7 . clin. Endocr. Metab. 27, 1167.

Plotka, E. D., ERb, R. E., Gallahan, C. J. \& Gomes, W. R. (1967) Levels of progesterone in peripheral blood plasma during the oestrous cycle of the bovine. F. Dairy Sci. 50, 1158.

Pope, G. S., Gupta, S. K. \& Munro, I. B. (1969) Progesterone levels in the systemic plasma of pregnant, cycling and ovariectomized cows. F. Reprod. Fert. 20, 369.

Rao, Ch. V. \& Estergreen, V. L. (1969) Determination of bovine plasma progesterone. F. Dairy Sci. 52,904 .

Rosenfield, R. L., Eberlein, W. R. \& BongrovanN, A. M. (1969) Measurement of plasma testosterone by means of competitive protein binding analysis. F. clin. Endocr. Metab. $29,854$.

Schwartz, N. B. (1969) A model for the regulation of ovulation in the rat. Recent Prog. Horm. Res. $25,1$.

Shemesh, M., Ayalon, N. \& Lindner, H. R. (1968a) Plasma progesterone concentrations in dairy cows during the oestrous cycle. Refuah vet. $25,270$.

Shemesh, M., Ayalon, N. \& Lindner, H. R. (1968b) Early effect of conceptus on plasma progesterone level in the cow. F. Reprod. Fert. 15, 161.

Stabenfeldt, G. H., Ewing, L. L. \& MaDonald, L. E. (1969) Peripheral plasma progesterone levels during the bovine oestrous cycle. F. Reprod. Fert. 19, 433. 